\title{
Attitudes of Students of the University of Split towards Asylum Seekers as a Realistic and a Symbolic Threat in the Context of Risk Society
}

\author{
Vlaho Kovačević* \\ vkovacevic@ffst.hr \\ https://orcid.org/0000-0001-8247-3941 \\ Krunoslav Malenica** \\ kmalenica@pmfst.hr \\ https://orcid.org/0000-0002-8445-2295 \\ Igor Jelaska**** \\ jelaska@kifst.hr \\ https://orcid.org/0000-0001-5566-5235
}

\author{
https://doi.org/10.31192/np.18.2.2 \\ UDK: 343.226-054.7(497.5) \\ 341.43-05:303.423-057.87(497.583) \\ Izvorni znanstveni rad / Original scientific paper \\ Primljeno / Received: \\ 15. veljače 2020. / Feb 15, 2020 \\ Prihvaćeno / Accepted: \\ 12. svibnja 2020. / May 12, 2020
}

The aim of this research was to analyze the attitudes of the student population at the University of Split towards asylum seekers as a multidimensional threat to the community in the context of risk society. We have approached the empirical data collection within a multidimensional theoretical framework. The first part of our subject interest is the theoretical direction of reflexive modernity and risk society proposed by Ulrich Beck, while the second part deals with the theoretical explanations regarding the perception of asylum seekers as a threat. In accordance with the research objective, a stratified sample of 286 Croatian students from the University of Split expressed their attitudes toward asylum seekers using a scale. Reliability of the used questionnaire was assessed by using test and retest method. Results indicate that students perceived asylum seekers as a statistically significantly more realistic than a symbolic threat. The respondents thus recognize one, equally important yet diffuse phenomenon showing interest among the respondents for the rational choice but also for respecting the individual's subjectivity.

Keywords: asylum seekers, risk society and subpolitics, students, symbolic or realistic threat, University of Split.

\footnotetext{
*Vlaho Kovačević, PhD, Assis. Prof., University of Split, Faculty of Humanities and Social Sciences, Department of Sociology; Address: Poljička cesta 35, HR-21000 Split, Croatia.

** Krunoslav Malenica, assistant, University of Split, Faculty of Natural Sciences and Mathematics, Independent Chair of Humanities and Social Sciences; Adress: Ruđera Boškovića 33, HR21000 Split, Croatia.

***: Igor Jelaska, PhD, Assoc. Prof., University of Split, Faculty of Kinesiology; Address: Nikole Tesle 6, HR-21000 Split, Croatia.
} 


\section{Introduction}

In a globalized society, an individual faces various threats within which there are various risks and dangers associated with social processes of individualization and globalization. Social processes of individualization and globalization point to the historical social context within which asylum seekers as symbolic and realistic threats are researched. This horizon changes the way of approaching the migration phenomenon, respecting the views, and they are no longer ethnocentric, west-centric, or related to the national state. At the same time, they teach us to think globally transcending the »methodological individualism " criticized by Ulrich Beck. ${ }^{1}$ The threat as a sign of time impels responsibility of the community towards asylum-seekers, i.e. the responsibility for the world of globalization in which asylum-seekers live, encouraging us to analyze social facts, taking into account their world dimension.

The symbolic threat of asylum seekers, in the context of risk society as the second modernity, ${ }^{2}$ is a cultural threat, and it implies a threat to the lifestyle of a member of a particular society or group from asylum seekers. Symbolic threats to the community are therefore primarily related to the issues of values and norms perceived by members of their own groups as compared to members of other groups ${ }^{3}$ and mostly result from the belief in the moral validity of the value system of their own group. ${ }^{4}$ On the other hand, threats to the community also imply real social, political, economic and other factors that endanger physical and material well-being, social, political and economic power of members of their own group. ${ }^{5}$

Understanding the community in the context of various threats was an important topic of the first modernity within some of the most influential universalist political ideologies of modern period, especially those that marked the period between 1830 and 1989. This covers the period between the depletion and weakening of the Enlightenment, on the one hand, and the collapse of socialist social systems, on the other. ${ }^{6}$ According to the nationalist concept of the community, the nation - best achieved in the political form of the state - exists only as an expression of the original reality: »a cultural community shaped by

\footnotetext{
${ }^{1}$ Ulrich BECK, War is peace: On post-national war, Security Dialogue, 36 (2005) 1, 5-26.

2 Ulrich BECK, The Risk Society: Towards a New Modernity, London, Sage, 1996.

${ }^{3}$ Cicero PEREIRA, Jorge VALA, Rui, COSTA-LOPES, From prejudice to discrimination: The legitimizing role of perceived threat in discrimination against immigrants, European Journal of Social Psychology, 40 (2010) 7, 1231-1250.

4 Walter G. STEPHAN, Oscar YBARRA, Guy BACHMAN, Prejudice Toward Immigrants, Journal of Applied Social Psychology, 29 (1999) 11, 2221-2237.

5 Pereira, Vala, Costa-Lopes, From prejudice to discrimination..., 1231-1250; Stephan, Ybarra, Bachman, Prejudice Toward Immigrants'..., 2221-2237.

${ }^{6}$ Gerard DELANTY, Community, London - New York, Routledge, 2018, 20-21.
} 
common history, language, customs, etc. $\ll^{7}$ It is an opinion that is integralistic and dualistic, exclusive and fundamentalistic.

The most important political ideologies of this turbulent period had in their foundations certain concepts of the community, which, though, functioned many times as a normative ideal. All of them, therefore, were distinguished by a peculiar »utopian imagination «, a desire for something else and significantly different from what exists. ${ }^{8}$ Their influence has not been lost even today, although these ideologies have experienced significant transformations within the new modernity and the process of globalization, individualization, gender revolution, unemployment and global threats. ${ }^{9}$ In that sense, an important, but diffuse phenomenon on the rise is individualism in all its dimensions. "This rise has emerged very early in the research interest in the theory of rational choice, but recently and increasingly in the respect of the subjectivity of individuals. ${ }^{10} \mathrm{New}$ community manifestations are emerging in the society in terms of creating the Internet with its growing power, and with its changing way of communication which creates fragmentation and the possibility of new social connections. The contemporary community thus becomes a communication community based on belonging and sharing and can be a powerful voice of political opposition through the influence of recent political projects inspired by the idea of »the third path $"$ (for the first time). ${ }^{11}$

From this broader context and the global experience of contemporary living not even the Republic of Croatia is excluded. Therefore, this paper researches attitudes of the students of the University Split towards asylum seekers regarding their symbolic and realistic threat to the community. This is a major challenge for the Republic of Croatia, regardless of whether we talk about economic or forced asylum seekers that are the result of wars and development of the states. ${ }^{12}$ We have accessed our subject of interest in theoretical direction of

\footnotetext{
${ }^{7}$ Marija GEIGER ZEMAN, Zdenko ZEMAN, Uvod u sociologiju (održivih) zajednica, Zagreb, Institut društvenih znanosti Ivo Pilar, 2010, 16-17.

${ }^{8}$ Delanty, Community..., 20-21.

9 Ulrich BECK, The Invention of Politics, Cambridge, Polity Press, 1997; Ulrich BECK, The Reinvention of Politics: Rethinking Modernity in the Global Social Order, Cambridge, Polity Press, 1997; Ulrich BECK, World Risk Society, Cambridge, Polity Press, 1999.

${ }^{10}$ Craig, CALHOUN, Michel WIEVIORKA, Manifest za društvene znanosti, Zagreb, TIM press, 2017, 21.

${ }^{11}$ Geiger Zeman, Zeman, Uvod u sociologiju..., 7.

${ }^{12}$ Pereira, Vala, Costa-Lopes, From prejudice to discrimination...; Zlatko ŠRAM, Etnocentrizam, percepcija prijetnje i hrvatski nacionalni identitet, Migracijske i etničke teme, 26 (2010) 2, 113 142; Renata FRANC, Vlado ŠAKIĆ, Ljiljana KALITERNA-LIPOVČAN, Percipirane posljedice doseljavanja i stav prema doseljavanju, Društvena istraživanja, 19/3 (2008) 107, 421-440; Margareta GREGUROVIĆ, Simona KUTI, Drago ŽUPARIĆ-ILJIĆ, Attitudes towards Immigrant Workers and Asylum Seekers in Eastern Croatia: Dimensions, Determinants and Differences', Migracijske i etničke teme, 32 (2016) 1, 91-122; Sandra BENČIĆ, Emina BUŽINKIĆ, Goran MILETIĆ, Andrijana PARIĆ, Drago ŽUPARIĆ-ILJIĆ, Azil u Hrvatskoj - Analiza rezultata istraživanja, Zagreb, Centar za mirovne studije, 2005.
} 
reflexive modernity and the risk society of Ulrich Beck and theoretical explanations of understanding asylum seekers as a threat.

\section{Theoretical direction of reflexive modernity and the risk society of Ulrich Beck}

The dynamics of social processes and the structure of society in new modernity seek new understanding of asylum seekers in relation to the former term used in the modern period. According to some modern sociologists, we can distinguish the first and the new modernity. The first modernity was based on nation-state societies, where social relations, networks and communities are essentially understood in a territorial sense. ${ }^{13}$ The collective patterns of life, progress and controllability, full employment and exploitation of nature that were typical of the first modernity have been undermined in the new modernity by five interlinked processes: globalization, individualization, gender revolution, underemployment and global risks (such as ecological crisis and the crash of global financial markets).$^{14}$ It is the shock that encompasses and electrifies all fields of action in modern society ${ }^{15}$ which needs a paradigm shift, a new frame of reference, from which it is necessary to interpret a new way of symbolic and realistic threats posed by asylum seekers.

That is the task of the second modernity that puts us before the sociology reform so that it can get a new framework for reinvention, society and politics. ${ }^{16}$ This new framework for the understanding of modernity needs to be obtained first of all through (reformed) sociology, within a socio-historical and cultural context in which »ontology of risk as such does not grant privilege to any specific form of knowledge, but forces everyone to combine different, and often divergent rationality-claims, to act and react in the face of contradictory certainties ${ }^{17}{ }^{17}$

Relations towards asylum seekers in new modern society develop not only by rising against its own (industrial) assumptions and limitations and destroying its own coordinate system - set along the axis of gender, family, occupation, faith in science and technical progress, etc. In the late, reflexive modernity, the motor of social change is no longer an instrumental rationality, but this role is taken by the »side effects « of development: risks, dangers, individualization and globalization.

\footnotetext{
${ }^{13}$ Beck, World Risk Society..., 1-2.

${ }^{14}$ Ibid..., 2.

${ }^{15}$ Beck, The Reinvention of Politics..., 151.

${ }^{16}$ Beck, World Risk Society..., 2.

${ }^{17}$ Ibid..., 4.
} 
In our paper, the differences in attitudes towards asylum seekers are articulated within reflexive modernization and political order towards asylum seekers, in which the ubiquitous (political) left and right metaphors no longer make any sense. However, their attractiveness will only fade more seriously to the extent to which new, more appropriate conceptual dichotomies will be affirmed. We are primarily concerned with three categorical pairs (and their key questions): ${ }^{18}$

(1) the dichotomy safe - unsafe, connected with the key question: What is your attitude towards uncertainty?

(2) the dichotomy inside - outside, connected with the key question: What is your attitude towards strangers?

(3) the dichotomy political - non-political, connected with the key question: What is your attitude towards the possibility of shaping society?

These questions have been chosen because, $»$ in the perspective of the theory developed here, they have greater opportunities for implementation, or more clearly, opportunities for stylization and stage management than others «.$^{19}$ If the asylum politics towards asylum seekers fails to articulate and affirm in the indicated form, the need for simplicity and rigidity will increase and the counter-modernization will certainly get a new impetus. In the arsenal of resources for these purposes there are various possibilities: nationalism, violence, esotery etc., or some of their combinations. ${ }^{20}$

\section{Theoretical interpretative frames of understanding asylum seekers as a threat}

There are different theoretical approaches that explain negative attitudes towards asylum seekers. ${ }^{21}$ Generally, citizens' attitudes about the consequences of immigration can be understood as a synergy of the perception of economic, cultural and security threats. According to the approach that explains positions from the perceived threat position, attitudes are manifested as symbolic or realistic threats, primarily threatening the cultural identity and economic

\footnotetext{
${ }^{18}$ Beck, The Reinvention of Politics..., 149-150; Anthony GIDDENS, Scott LASH, Living in a PostTraditional Society, in: Ulrich BECK, Anthony GIDDENS, Scott LASH (eds.), Reflexive Modernization, Stanford, Stanford University Press, California, 1994, 42.

${ }^{19}$ Beck, World Risk Society..., 2; Beck, Giddens, Lash (eds.), Refleksive Modernization..., 42.

${ }^{20}$ Beck, The invention of Politics..., 150.

${ }^{21}$ Natascha KLOCKER, Kevin DUNN, Who's driving the asylum debate? Newspaper and government representations of asylum seekers, Media International Australia, 109 (2003) 1, 7192.
} 
stability of the receiving country. ${ }^{22}$ Socioculturally-oriented explanations refer to the fear of possible negative social and cultural consequences of immigration, while economically-oriented explanations of negative attitudes towards immigrants are perceived as a consequence of the fear of the majority population of losing their own socioeconomic position/privilege. ${ }^{23}$

Pereira, Vala and Costa-Lopes ${ }^{24}$ noted that the association between (symbolic and realistic) threat and prejudiced attitudes has been exhaustively analyzed by several theories and models, such as the group position theory, ${ }^{25}$ the realistic group conflict theory, ${ }^{26}$ the instrumental model of group conflict, ${ }^{27}$ the sociofunctional threat-based approach ${ }^{28}$ and the integrated threat theory of prejudice. ${ }^{29}$

In the newest version of intergroup threat theory, Stephan, Ybarra and Morrison ${ }^{30}$ consider two main types of threats that ingroups experience from outgroups. These are realistic threats, which refer to the physical welfare or resources of the ingroup, and symbolic threats, which refer to the ingroup's system of meaning. According to the authors, these two types of threats can be experienced at the group level or individual level and have many antecedents which funnel down from distal factors to more specific factors. Therefore, people's responses to perceived threat from outgroups can occur at the individual level, but can also include responses that influence the dynamics and relations between the ingroup and the outgroup. Further, the behavior of each group affects the responses and perceptions of the other group. If the outgroup

${ }^{22}$ Drago ŽUPARIĆ-ILJIĆ, Margareta GREGUROVIĆ, Stavovi studenata prema tražiteljima azila u Republici Hrvatskoj, Društvena istraživanja, 22 (2013) 1, 41-62, 43.

${ }^{23}$ Ibid, 43-44.

${ }^{24}$ Pereira, Vala, Costa-Lopes, From prejudice to discrimination....

${ }^{25}$ Herbert BLUMER, Race prejudice as a sense of group position, Pacific Sociological Review, 1 (1958) 1, 3-7; Lawrence D. BOBO, Prejudice as group position: Micro foundations of a sociological approach to racism and race relations, Journal of Social Issues, 55 (1999) 3, 445-472.

${ }^{26}$ Robert A. LeVINE, Donald T. CAMPBELL, Ethnocentrism, New York, John Wiley \& Sons, 1972; Muzafer SHERIF, Group conflict and cooperation, London, Routledge and Kegan Paul, 1966.

${ }^{27}$ Victoria M. ESSES, Lynne M. JACKSON, Tamara L. ARMSTRONG, Intergroup competition and attitudes toward immigrants and immigration: An instrumental model of group conflict, Journal of Social Issues, 54 (1998) 4, 699-724.

${ }^{28}$ Catherine A. COTTRELL, Steven L. NEUBERG, Different emotional reactions to different groups: A sociofunctional threat-based approach to "prejudice«, Journal of Personality and Social Psychology, 88 (2005) 5, 770-789.

${ }^{29}$ Walter G. STEPHAN, Lausanne, RENFRO, The role of threat in intergroup relations, in: Diane M. MACKIE, Eliot R. SMITH (eds.), From prejudice to intergroup emotions: Differentiated reactions to social groups, New York, Psychology Press, 2002, 191-207; Walter, G. STEPHAN, Cookie W. STEPHAN, An integrated threat theory of prejudice, in: S. OSKAMP (ed.), »The Claremont Symposium on Applied Social Psychology« Reducing prejudice and discrimination, Mahwah, Lawrence Erlbaum Associates, 2000, 23-45.

${ }^{30}$ Walter G. STEPHAN, Oscar YBARRA, Rios MORRISON, Intergroup threat theory, in: Todd D. NELSON (ed.), Handbook of Prejudice, Mahwah, Lawrence Erlbaum Associates, 2009, 4355. 
responds with counter-aggression, this will change the ingroup's perceptions of the level of conflict between the groups and increase their perceptions of threat. Similarly, the responses of the outgroup can affect other variables considered to be antecedents of threat in the theory. Threats to an ingroup can influence attitudes, beliefs, and ideologies that are typically thought to remain invariant over time and across situations. Moreover, the ingroup's own responses to threat will feed back into its perceptions of the outgroup, usually augmenting them although sometimes attenuating them. ${ }^{31}$

Inclusive, correlational studies have supported these models showing that both realistic ${ }^{32}$ and symbolic threat ${ }^{33}$ predict prejudice ${ }^{34}$ Certainly, among the European (and Croat) population, every new migratory wave or terrorist attack increases the perceived asylum seekers' threat. European policy makers often move their existing state of affairs simply by refusing to make a clear strategy for the future coexistence in Europe.

Therefore, in accordance with the above-mentioned issue, this paper focuses on the extent to which Croatian students from the University of Split perceive asylum seekers as a realistic threat (in terms of health and economic threat) and to what extent as a symbolic (cultural) threat, and whether there is a statistically significant difference between these two perceptions. In other words, we are interested if asylum seekers in students' view are a realistic or a symbolic threat (or both) and to what extent the threat is generally perceived.

\footnotetext{
${ }^{31}$ Ibid, 54.

${ }^{32}$ Lawrence D. BOBO, Whites' opposition to busing: Symbolic racism or realistic group conflict? Journal of personality and Social Psychology, 45 (1983) 6, 1196-1210; Victoria M. ESSES, John F. DOVIDIO, Lynne Marie JACKSON, Tamara L. ARMSTRONG, The immigration dilemma: The role of perceived group competition, ethnic prejudice, and national identity, Journal of Social Issues, 57 (2001) 3, 389-412; Lincoln, QUILLIAN, Prejudice as a response to perceived group threat: Population composition and anti-immigrant and racial prejudice in Europe, American Sociological Review, 60 (1995) 4, 586-611; Walter G. STEPHAN, Lausanne RENFRO, The role of threat in intergroup relations, in: Diane M. MACKIE, Eliot R. SMITH (eds.), From prejudice to intergroup emotions: Differentiated reactions to social groups, New York, Psychology Press, 2002, 191-207.

${ }^{33}$ Victoria M. ESSES, Geoffrey HADDOCK, Mark P. ZANNA, Values, stereotypes, and emotions as determinants of intergroup attitudes, in: Diane M. MACKIE, David L. HAMILTON (eds.), Affect, cognition, and stereotyping: Interactive processes of group perceptions. San Diego, Academic Press, 1993, 137-166; Donald R. KINDER, David O. SEARS, Prejudice and politics: Symbolic racism versus racial threats to the good life, Journal of Personality and Social Psychology, 40 (1981) 3, 414-431; David O. SEARS, Paulette J. HENRY, The origins of symbolic racism, Journal of Personality and Social Psychology, 85 (2003) 2, 259-275; Stephan, Renfro, The role of threat in intergroup relations..., 191-207.

${ }^{34}$ Pereira, Vala, Costa-Lopes, From prejudice to discrimination..., 1232.
} 


\section{Methods}

\subsection{Sample}

In this research a stratified random sample consisted of 286 students (39.1\% male; $60.9 \%$ female) from the University of Split. Strata included study groups: social sciences $\left(\mathrm{N}_{1}=77\right)$, humanities $\left(\mathrm{N}_{2}=70\right)$, science $\left(\mathrm{N}_{3}=71\right)$ and engineering $\left(\mathrm{N}_{4}=68\right)$. Students were contacted by trained professionals. After brief introduction, each participant was given a choice to quit or to continue so the overall respondent rate was $93.7 \%$. Participants were fully aware of the research objective and the study protocol was done in accordance with the Declaration of Helsinki and additionally approved by the institution ethics committee.

\subsection{Measures}

We used the measuring instrument $»$ The scale of attitudes toward asylum seekers $«,{ }^{35}$ which was previously identified as a three factor with identified factors: perception of social threat, perception of cultural threat and perception of health and economic threat. Participants were asked to answer 8 questions about the attitudes towards asylum seekers using the Likert type scale ranging from 1 (I strongly disagree) to 5 (I strongly agree):

1. could help asylum seekers if I can.

2. I would like that asylum seekers are similar to the Croat population in their nationality.

3. I would like the asylum seekers in Croatia have a similar skin color to the Croatian population.

4. The culture of asylum seekers should not be mixed with the Croatian culture.

5. Asylum seekers are not a threat to epidemic contamination at the shelter where they are staying.

6. Asylum seekers are not a burden on taxpayers.

7. Asylum seekers are not a health threat in the community.

8. Asylum seekers are not a burden to the economic development of our country.

As modified from Župarić-Iljić and Gregurović, ${ }^{36}$ first statement was assumed to be an indicator of participant's perception of asylum seekers as social

\footnotetext{
${ }_{35}$ Župarić-Iljić, Gregurović, Stavovi studenata prema tražiteljima azila u Republici Hrvatskoj... ${ }^{36} \mathrm{Ibid}$.
} 
threats. Second, third and fourth statement were assumed to be indicators of participant's perception of asylum seekers as a cultural threat while last four statements were assumed to be indicators of participant's perception of asylum seekers as a health and economic threat.

\subsection{Statistical analysis}

Reliability of the used questionnaire was assessed by test-retest method on randomly chosen subsample of 31 participants. Cronbach alpha $(\mathrm{C} \alpha)$ was used as internal consistency indicator. Between-items correlation matrix was calculated and factor structure was examined by application of exploratory factor analysis. Construct validity was assessed by proportion of variance accounted (TotVar\%) by extracted factors. Number of significant factors was determined by using Scree criterion and initial factor structure was rotated by using varimax raw rotation. The average value of items highly correlated with the factor (observed through factor structure matrix) was taken as participant's result in single factor. Results in factors were presented as mean \pm standard deviation. One way within-subjects ANOVA was used for identification of significance of differences between participant's attitudes. Partial eta squared (partial $\eta^{2}$ ) was used as effect size assessment. Type I error was set at $\alpha=5 \%$. All calculations were performed by using software system Statistica 13.2. (DellInc., Tulsa, OK, USA).

\subsection{Results}

Retest reliability was calculated on the subsample of 31 randomly chosen participants and clearly indicated excellent reliability $(r=0.87 ; p<0.001)$ of the used questionnaire. Inter-item correlation matrix and mean values of questionnaire items are presented in table 2.

Table 2: Inter-item correlation matrix and mean value \pm standard deviation $($ Mean $\pm \sigma)$

\begin{tabular}{|c|c|c|c|c|c|c|c|c|}
\hline & Q1 & Q2 & Q3 & Q4 & Q5 & Q6 & Q7 & Mean $\pm \sigma$ \\
\hline Q1 & & & & & & & & $3.61 \pm 1.06$ \\
\hline Q2 & -0.06 & & & & & & & $3.17 \pm 1.20$ \\
\hline Q3 & $-0.18^{*}$ & $0.44^{*}$ & & & & & & $2.28 \pm 1.19$ \\
\hline Q4 & $-0.26^{*}$ & $0.28^{*}$ & $0.24^{*}$ & & & & & $3.05 \pm 1.24$ \\
\hline Q5 & $0.28^{*}$ & $-0.12^{*}$ & -0.08 & $-0.20^{*}$ & & & & $3.14 \pm 0.99$ \\
\hline Q6 & $0.29^{*}$ & $-0.20^{*}$ & -0.05 & $-0.18^{*}$ & $0.56^{*}$ & & & $2.73 \pm 0.95$ \\
\hline Q7 & $0.29^{*}$ & $-0.16^{*}$ & $-0.16^{*}$ & $-0.26^{*}$ & $0.75^{*}$ & $0.57^{*}$ & & $3.13 \pm 0.98$ \\
\hline Q8 & $0.41^{*}$ & $-0.27^{*}$ & $-0.13^{*}$ & $-0.26^{*}$ & $0.49^{*}$ & $0.71^{*}$ & $0.58^{*}$ & $2.76 \pm 1.05$ \\
\hline
\end{tabular}

"significant correlation at $\mathrm{p}<0.05$ 
While observing table 1 , existence of an underlying construct whose manifestation are items Q1-Q8 can be assumed to exists. Additionally, due to construct validity assessment, factor analysis with varimax raw rotation of initial factor structure was used (Table 3).

Table 3: Factor structure matrix after varimax raw rotation.

\begin{tabular}{|c|c|c|}
\hline & Health \& economy threat & Cultural threat \\
\hline Q1 & 0.61 & -0.01 \\
\hline Q2 & -0.03 & 0.82 \\
\hline Q3 & -0.00 & 0.79 \\
\hline Q4 & -0.14 & 0.67 \\
\hline Q5 & 0.83 & 0.03 \\
\hline Q6 & 0.83 & -0.01 \\
\hline Q7 & 0.86 & -0.04 \\
\hline Q8 & 0.82 & -0.16 \\
\hline ExplVar & 3.19 & 1.77 \\
\hline TotVar\% & 0.40 & 0.31 \\
\hline
\end{tabular}

Legend: Expl Var - variance accounted by the single factor; PropTotl - proportion of variance accounted by the single factor.

As can be seen in table 3, due to relatively large correlations with Q1, Q5-Q8 and Q2-Q5 extracted factors are interpreted as Health E economy threat and Cultural threat, respectively. Extracted factors accounted for $71 \%$ of variance, therefore the construct validity was interpreted as satisfactory. As a measure of internal consistency, Cronbach Alpha was calculated for both Health $\mathcal{E}$ economy threat $(\mathrm{C} \alpha=0.83)$ and Cultural threat $(\mathrm{C} \alpha=0.68)$, and also appeared to be satisfactory. After factors were identified, average value of items was used to assess participants' results in both factors. By using one-way within-subjects, ANOVA results in students' perception of asylum seekers as Health \& economy threat $(3.07 \pm 0.77)$ to be significantly higher $\left(\mathrm{F}_{1,285}=9.10 ; \mathrm{p}=0.002 ; \eta^{2}=0.031\right)$ than as Cultural threat $(2.83 \pm 0.89)$.

\section{Discussion and conclusion}

First of all, it should be noted that the two factors structure of the questionnaire was identified, which was modified in relation to the assumption of the existence of 3 factors. The aforementioned additionally points to the complexity and dynamical structure of the interaction of observed dimensions on a sample of the students of the University of Split.

This study implicitly shows that students within the Croatian social context successfully recognize not only the symbolic $(\mathrm{M} \pm \mathrm{SD}: 2.83 \pm 0.89)$ but also the 
realistic social threat $(\mathrm{M} \pm \mathrm{SD}: 3.07 \pm 0.77)$ from asylum seekers. Many years ago, Bogardus ${ }^{37}$ noted that there are indications that in the circumstances in which »natives « feel more vulnerable or think their (social, economic, health) status is questioned, the value of social distance increases. It is therefore expected that in the period of the growing number of asylum seekers in the territory of the Republic of Croatia, perceived threats will arise.

Since we talk about students who represent the future of (Croatian) society, the obtained results point to the relevance of the observed issues, not only in the context of current events and processes, but also for issues of long-term stability and functioning. The results obtained are certainly a result of the existing socio-political context and the historical situation in Europe. As pointed out by Parrillo and Donoghue, ${ }^{38}$ external influences or circumstances under which research is conducted strongly influence the degree of distance that members of a particular group/society express in a certain period. Such circumstances certainly produce new cultural struggles for identity and material status, concern, withdrawal and silence, which does not allow us to look at the problem of the asylum seekers' position, which is necessary if wishing to make professional and valid conclusions about them, ourselves and others.

Furthermore, it should be emphasized that students statistically significantly more perceive asylum seekers as realistic than symbolic threats $(\mathrm{p}=$ 0.002), as confirmed by the researches already carried out ${ }^{39}$ on this topic. The results point to the necessity of integrating the historical situation of the migration phenomena into the social context, characterized by rapid cultural transformations, and pointing to the process of separation and determination of boundaries between personal identities and culture. In such situations, the public is ready, even at the cost of violence and dehumanizing action, to agree with the options offered by the so-called "protection«. In fact, it is an existential threat that leads to insecurity and an unpredictable future, creating fear and discomfort for most people. In addition, the results of our research show that the fear of the realistic threat (health, safety and economy) is greater than fear of the symbolic (cultural) threat.

The reason for this can be found in the context of the results of Pereira, Vale and Costa-Lopez, ${ }^{40}$ who understood the symbolic and realistic threat under the political restrictive measures in the »countries of reception« of immigrants/asylum seekers. Namely, depending on whether the stressed problems of reducing the number of immigrants or aggravating their naturalization are also variable values of the perception of realistic or symbolic threats. Authors

\footnotetext{
${ }^{37}$ Emory, S. BOGARDUS, Social Distance in the City. Proceedings and Publications of the American Sociological Society, 20 (1926) 40-46.

${ }^{38}$ Vincent, PARRILLO, Christopher DONOGHUE, The National Social Distance Study: Ten Years Later, Sociological Forum, 28 (2013) 3, 597-614.

${ }^{39}$ Pereira, Vala, Costa-Lopes, From prejudice to discrimination...

${ }^{40}$ Ibid.
} 
emphasize that opposition to immigration has been more closely connected to the idea that immigrants represent both economic and security threats, i.e. this opposition is recurrently linked more to the realistic than to the symbolic threat. On the other hand, opposition to naturalization may involve symbolic threat, because if the host country adopts a policy facilitating the naturalization of immigrants (i.e. if they turn »them « into »us«), people might conclude that the values and traditions that define the country's cultural identity could be »contaminated « and »altered « by mixing it with values and tradition, characterizing the cultural identity of naturalized people. ${ }^{41}$

The framework of reflexive modernity (Beck) shows that, as long as the rational choice and the hierarchical model of means and goals are dominant, every attempt to solve migration phenomenon and its associated problems is a futile act. Whether or not they are present in the area of symbolic (values and traditions that define the cultural identity of the country) or realistic threat (through issues of endangerment of life security and material well-being). It is possible to identify biopolitics as a factor that has ruined the foundations for the return of history, culture and identity. ${ }^{42}$ Therefore, in the ideologicalpolitical field as the ideology of the nation and the ideology of religion, as well as early modernity, it is not possible to find formulas in order to extract Croatian society from the cultural-identity and modernization crisis that arises in the process of migration.

Unmasking this process can be not only an initial impulse, ${ }^{43}$ but also a supportive point in the context of late modernity and its most appropriate form of politics - subpolitics towards asylum seekers, and it succeeds in articulating itself as a reflexive policy towards asylum seekers. Late modernity, in a paradigmatic way, calls for the relation to symbolic threats, between the national and the religious, to re-examine in a manner that emphasizes consultation, interaction, negotiation, social networks - that is, the interdisciplinary and process character of decision-making - the creation in the context of relations between responsible and life-social actors.

According to Beck, this whole story of risk society can be defined as a »systematic way of dealing with the dangers and uncertainties that provokes and introduces modernization by itself $«{ }^{44}$ It is clear that the risk as such did not arise only with modernity, but only in the conditions of modernity it was transported from a personal matter (connected with courage, adventure, etc.) into global danger, moreover, in a serious threat in which discrimination is justified or relativized, intolerance and, ultimately, the crimes themselves.

\footnotetext{
${ }^{41}$ Ibid, 1233.

42 Žarko, PAIĆ, Politika identiteta: kultura kao nova ideologija, Zagreb, Antibarbarus, 2005, 5.

${ }^{43}$ Krunoslav MALENICA, Vlaho KOVAČEVIĆ, Goran KARDUM, Impact of religious Self Identification and Church Attendance on Social Distance toward Muslims, Religions, 10 (2019) 4, 1-18.

${ }^{44}$ Beck, World Risk Society..., 21.
} 
The scientific foundation of identified problems is the first step in any discussion with the Other and the different. The problems are those that require a much larger and more complex public and scientific debate. A discussion that will not result in having a politically ideologically divided population within political destruction but expert and valid conclusions on the most appropriate strategies for future developments and further research. In order to understand the whole situation, it is necessary to recognize in the modernity the multidimensional character of social processes. In our case, this means to recognize conflicting lines (anti-immigrant, populist and radical right parties) towards asylum seekers, with the aim of concrete proposals of good practice and policy recommendations that can contribute to improving asylum seeker conditions. Consequently, both sides must constantly keep under control its bias, the fulfillment of its desires and interests, making visible the other, respecting its opinion in the context of tradition and healthy historical impacts. This is a necessary prerequisite for achieving social consensus and making a general strategy of action without which any society can hardly achieve the necessary stability and ultimately develop. 


\section{Vlaho Kovačević ${ }^{* *}$ - Krunoslav Malenica** - Igor Jelaska**** \\ Stavovi studentske populacije Sveučilišsta u Splitu o azilantima kao simboličkoj i realnoj prijetnji u kontekstu društva rizika}

\section{Sažetak}

Cilj ovog istraživanja bilo je analiziranje stavova studentske populacije Sveučilišta u Splitu prema tražiteljima azila kao višedimenzionalnoj prijetnji zajednici u kontekstu društva rizika. Pristupili smo empirijskom prikupljanju podataka unutar višedimenzionalnog teorijskog okvira. Prvi dio našeg interesa tema je teorijskog smjera refleksivne modernosti i društva rizika Ulricha Becka, dok se drugi bavi teorijskim objašnjenjima percepcije tražitelja azila kao prijetnje. U skladu s ciljem, na stratificiranom uzorku od 286 studenata Sveučilišta u Splitu, rezultati ukazuju na odgovarajuću pouzdanost opaženu putem korelacije ispitivanja i ponovnog testiranja $(\mathrm{r}=0,87$; $\mathrm{p}<0,001)$, kao i konstruktnu valjanost utvrđenu faktorskom analizom s varimax row rotacijom (Expl Var $=$ $71 \%)$. Nadalje, ANOVA je otkrila da su studenti azilante statistički značajno više shvaćali kao stvarnu nego simboličku prijetnju. Sudionici tako prepoznaju jedan, ne manje važan, ali difuzni fenomen koji među njima pokazuje interes za racionalan izbor, ali i za uvažavanje subjektivnosti subjekta o kojem se raspravlja i rješava svaki pokušaj migracijskih pojava i s tim povezanim problemima. Buduća istraživanja trebaju se usredotočiti na ovu promjenu pristupa prema azilantima, što će omogućiti da se problem istraži i iz pozicije tražitelja azila, što je potrebno želimo li o sebi i drugima donijeti stručne i valjane zaključke.

Ključne riječi: azilanti, društvo rizika i sub-politika, simbolička i(li) realna prijetnja, studenti, Sveučilište u Splitu.

"Doc. dr. sc. Vlaho Kovačević, Sveučilište u Splitu, Filozofski fakultet, Odsjek za sociologiju; Poljička cesta 35, HR-21000 Split; E-mail: vkovacevic@ffst.hr.

** Krunoslav Malenica, mag. soc., naslovni asistent, Sveučilište u Splitu, Prirodoslovnomatematički fakultet, Samostalna katedra za društvene i humanističke znanosti; Ruđera Boškovića 33, HR-21000 Split, E-mail: kmalenica@pmfst.hr.

***: Izv. prof. dr. sc. Igor Jelaska, Sveučilište u Splitu, Kineziološki fakultet; Nikole Tesle 6, HR21000 Split, E-mail: jelaska@kifst.hr. 